\title{
A kölcsönös segítség mint természettörvény
}

\author{
VIRGINÁS ZOLNA ${ }^{1}$
}

\section{Bevezetés}

\begin{abstract}
„Ne harcoljatok! - A harc és versengés mindig kárt okoz a fajnak és nagyon sok módotok van az elkerülésre! Ez a természet tendenciája, ami nem teljesül mindig tökéletesen, de mindig hatékony. Ez a jelszó hangzik felénk a bokorból, az erdőből, a folyóból és a tengerből. Azért tehát egyesüljetek, gyakoroljátok a kölcsönös segítséget! Ez a legbiztonságosabb mód, amelynek segítségével mindegyik megszerezheti magának a legnagyobb biztonságot, a létezés és a testi, szellemi és erkölcsi haladás legerősebb biztosítékait. Ezt tanítja a természet és ezt tették mindazok az állatok, melyek a saját osztályukban a fejlődés legmagasabb fokára eljutottak. Ezt tette az ember, a legprimitívebb ember is és ezért érte el az ember azt a fokot, amelyen mi állunk." (Kropotkin 1924: 59)
\end{abstract}

A szabadversenyes kapitalizmus korszakában az iparmágnások a kor uralkodó egyenlőtlenségeinek igazolására előszeretettel használták a szociobiológia alapvető paradigmáját, az evolúciót. Mint tudjuk, a darwini filozófiai, biológiai és szociológiai gondolkodás alapelve: a létért való küzdelem, melyet úgy definiál, mint folytonos harcot, küzdelmet, az egyének, fajok, fajták és társadalmak között. A létért való küzdelmet tekinti az evolúció mozgatórugójának, valamint az élet diverzitását és az új fajok megjelenését indukáló tényezőnek. Helytelenül úgy képzelték, mint valamiféle agresszív élethalál-küzdelmet, amelyben az alkalmasabb leigázza a kevésbé alkalmasat (Barash 1977).

Kropotkin 1924-ben megjelent könyve, a Kölcsönös segítség mint természettörvény, a darwini evolúciós paradigma ellenérve, tudományos cáfolata.

Kropotkin Péter 1842-1921 között élt orosz herceg, anarchista, geográfus. Szibériai és mandzsúriai utazásai során az állatvilágban tett tudományos megfigyelései alapján arra a következtetésre jutott, hogy a fejlődés legfontosabb tényezője a köl-

${ }^{1}$ PhD hallgató, Debreceni Egyetem, Humán Tudományok Doktori Iskola, Szociológia és társadalompolitika doktori program. 


\section{OLVASS FELESLEGESET!}

csönös segítség és támogatás. Az állatvilág felől közelítve világít rá a kölcsönös segítség múltjára és jelenére az emberiség történelmi fejlődésében. Amellett érvel, hogy a történelem folyamán az emberiség a föllendülés elemeit és nagy vonásait mindig a kölcsönös segítség által szerezte és ebből a forrásból eredtek mind az új gazdasági és társadalmi berendezések, mind pedig az új erkölcsi rendszerek, és vallások. Kropotkin végkövetkeztetése az, hogy a kölcsönös segítség hatékonyabb ösztönző erő, mint a létért való küzdelem.

\section{Kölcsönös segítség az állatok között}

Kropotkin az állatvilág etológiáját tanulmányozva bebizonyította, hogy a különböző gerinctelen és gerinces fajoknál a kölcsönös segítség fontosabb a túlélés szempontjából, mint a létért való küzdelem. Az ökoszisztémák megfigyelése során megállapította, hogy a természet nem darwini csatatér és nem is rousseau-i paradicsom, hanem a kettő ötvözete, ahol teret kap a fajok közötti pusztító harcok mellett a fajon belüli kölcsönös támogatás, kölcsönös segítség és kölcsönös védelem is. A társulás éppúgy természettörvény, mint a küzdelem. A kölcsönös segítséget az állatvilágban több faj etológiai szokásaiban is felfedezte: a temetőbogarak dögökbe való közös peterakásában; a hangyák, méhek társas életeben, munkamegosztásában; a fehérfarkú sas vadászatra való szövetségében; a pelikánok közös vadászatában; a verebek táplálékforrásról való kommunikációjában; a papagájok szociális életében, magasfokú intelligenciájuk használatában. A kölcsönös segítség magas fokát figyelte meg továbbá a madaraknál vonulásuk idején, a vonuló vagy legelésző növényevő csordáknál, de a ragadozók szociális szokásaiban is megtalálta: pl. oroszlánok közös vadászatában, rágcsálóknál a közös munkában vagy a mezei nyulak örömteli társas életében. „Az állatok egész természetét eltölti annak a szükségessége, hogy érzelmeiket egymásnak tudtul adják, játsszanak, csevegjenek, vagy legalább érezzék, hogy barátságos lények vannak a közelben, és mindez az életnek és az öntudatnak épp olyan szükségszerű alkatrésze, mint bármely más élettani müködés." (Kropotkin 1924: 46)

A társulási ösztön a fejlődés kezdeti faktora, mely elősegíti az értelem fejlődését. A társas élettel párhuzamosan fejlődnek a szociális érzékek, az igazságosság kollektív érzése, s ezek a faktorok serkentik a beszédet, az utánzást és az intelligenciát.

\section{Kölcsönös segítség a vad népek között}

A kölcsönös segítség a vad népek között fejezetben szépen bebizonyítja, hogy a vadember nem mintaképe a vadságnak és az emberiség sem érhette volna el fejlódésének a mai fokát, ha a régmúltban élő emberek nem rendelkeznek azzal a tulajdon- 


\section{OLVASS FELESLEGESET!}

sággal, hogy saját létüket azonosítsák a törzs létével. Viselkedésüket leírhatatlan illemszabályok hosszú sorozata befolyásolta, melyek sokszor babonába gyökereztek, de vakon engedelmeskedtek a közösségi jognak, mely életük és vallásuk közös tapasztalatainak volt az eredménye. A törzsön belüli legfőbb törvény a mindenki mindenkiért. Az emberi berendezkedések embriológiája szerint az emberi társadalmak csírája a társaságok, hordák, törzsek, melyek csak hosszú fejlődés után alakulnak poligám, majd monogám családokká. A kőkorszaki ember életmódját az antropológusok a svájci cölöpépítmények, a dániai kagylóhalmok és a történelem előtti archeológiai maradványok alapján, valamint a primitív törzsek megfigyelésével rekonstruálták. Kiemelték, hogy a szociális ösztönök mélyen gyökereznek az emberi viselkedésben, a primitív kommunizmus és a törzsi szolidaritás irányította, korlátozta, befolyásolta életüket. Kropotkin a busmanok, hottentották és eszkimók mindennapi tevékenységén keresztül mutatja be a kölcsönös segítség dominanciáját.

A busmanok életének rekonstruálását ellenségeik, az európaiak végezték el. A tanulmányok mégis pozitív képet festenek róluk: a törzs közösen vadászik, a zsákmányt veszekedés nélkül megosztják, sebesültjeiket sosem hagyják el, jószívűek, megbízhatóak és hálásak.

A hottentottákat - a legpiszkosabb állatok jelző mellett - fejlett szociális erkölcscsel ruházták fel. Dicsérték társas érzéküket, készségüket, ahogy egymáson segítettek. A legfontosabb hottentotta szokásként azt írták le, hogy nem tudnak egyedül enni, ha éhes, akkor is hívja a többieket, hogy megossza velük lakomáját. Legnagyobb örömüket a kölcsönös ajándékozásban és szívességben találják meg. Vidámak, szeretik a társaságot. Az időseket és gyerekeket szeretettel ápolják. A földjük köztulajdon. Közösen dolgoznak éppen annyit, hogy meglegyen a mindennapi kenyerük.

Az eszkimók hosszú házban élnek, melyben több család lakik együtt. Közös tüzet táplálnak. Amit vadászattal és halászattal szereznek, az a kláné. Az egyenlőség az alapelvük, a vagyont szétosztják. A szitkozódás illetlenségnek számít. Törzsi szolidaritás, jószívűség jellemzi őket.

A vademberek pejoratív jellemzőjeként sokszor a gyerekölést és az idősek elhagyását említik, de mindkettőt csak akkor alkalmazták, ha a törzs élete veszélyben forgott és legtöbbször nem gyilkoltak, hanem a természetben sorsára hagyták az áldozatot. Az idősek sokszor öngyilkosok lettek, búcsúszlogenük a következő volt: más emberek életét élem, ideje lesz menni. A kannibalizmust isteni eredetűnek tekintették, célja az ellenség bátorságának átöröklése volt.

\section{Kölcsönös segítség a barbárok között}

Kropotkin a barbárok népvándorlásainak okát a természetben bekövetkező hatalmas szárazságokban látta. Szerinte a szárazság előli menekülés rajzolja át a térképet és alakította ki a fejlődés következő lépcsőfokát, a faluközösséget, a klán szervezetek 


\section{OLVASS FELESLEGESET!}

természetes produktumát. A faluközösség lett a barbárok leghatékonyabb fegyvere, az ellenséges természettel folytatott bátor küzdelemben. Kifejlődik a közös földterület, területi szövetségek keletkeztek, melyek több szabadságot adtak az egyéni kezdeményezéseknek, biztosították a szükséges összefogást a gondolat és cselekvés között, és elég erősek voltak ahhoz, hogy ellenálljanak a varázslók, papok és kiváló harcosok uralkodási hajlamainak. A faluközösség elfogadta az ingó vagyon fölhalmozását a családon belül és annak átörökíthetőségét, de a magántulajdont vagy örök tulajdont nem. A föld a törzs közös tulajdona maradt. A faluközösség tulajdonképpen szövetkezés volt a közös földművelésre, védelemre, összetartásra és kölcsönös segítségre. A közösen termelt javakat elosztották, az ünnepektől eltekintve közös tűzhelyen főztek. Jogaikról a népgyűlés határozott. Intézmények keretében éltek, melyek eldöntötték mi a hasznos és mi a káros a törzsnek. Minden vita először a közvetítő vagy békebíró elé került. Igazság, erkölcs és cselekedet egymástól elválaszthatatlan volt számukra. A barbár ember legelső kötelessége az elkövetett hibát jóvátenni, valamint a szelídség és méltányosság alapelvei szerint cselekedni.

\section{Kölcsönös segítség a középkori városokban}

A faluközösségek békeszeretete volt a mozgatórugója a következő fejlődési stádiumnak. A tömegek konstruktív ereje létrehozta a középkori városokat, melyek várfalaikkal egyben a közös érdekeket is védték. A polgárok a népgyűlés révén kézben tartották az igazságszolgáltatást és a teljes önkormányzat jogát. Létrejött egy új egyesülési forma, a céh, amely biztonságot, védelmet és egyenlőséget jelentett tagjainak, de egyben szociális kötelességet is, konkrét szabályokkal, elvárásokkal, feltételekkel. A kölcsönös segítség elvére épülő céhek saját igazságszolgáltatással és katonai hatalommal rendelkeztek. Ünnepeik legfőképpen a testvériség megújítását szolgálták. A későbbi korokban a céhek egyesüléséből, szövetségéből jöttek létre a városok. Törvényeiket szabadságleveleik tartalmazták. Szabadságleveleiknek köszönhetően a hűbéri iga alatt élő terület közepén a középkori város egy megerősített oázis lett. Jogukban állt rendelkezni háború és béke felett, szomszédjaikkal szövetségeket köthettek. Önbíráskodásuk az önkormányzatok kialakulásához vezetett. A község, város maga lett az állam. Múködésük alapelve a szegények és gazdagok legszükségesebb táplálékáról és hajlékáról való gondoskodás volt. Az európai középkori városok éghajlati, fekvési, gazdasági, nyelvi és vallási különbségeik ellenére hasonló vezéreszmére épültek: önbizalom, föderalizmus és szuverenitás. Soha nem örvendett a munka akkora nagy közmegbecsülésnek, mint a városi élet virágkorában. A független városi élet időszakára esik az emberi szellem felvirágzása is. A termelésben és árucserében a közösség iránti méltányosság, a termelők és fogyasztók iránti igazságosság elve uralkodott. A termelés szociális kötelesség volt. A kézművesek minőségi áru termelésére törekedtek. A kézművesség megbecsült foglalkozás 


\section{OLVASS FELESLEGESET!}

volt, hét esztendei tanulás által vált valaki mesterré. A kézművesek organizációját külön hivatalnok végezte. A piac, középkori vásár védelem alatt állott, nem volt szabad viszálykodni ott senkinek. A középkori városok élete szakadatlan kemény küzdelem volt a szabadság megszerzéséért és biztosításáért. A harcok időszakában a viszálykodás és féltékenykedés egyetlen hatékony ellenszere a kölcsönös segítség volt. Ezekben a nehéz időkben felerősödött a szülőváros szeretete és kultusza. Fejlődött a kultúra, ekkor építettek sok, napjainkban is megcsodálható múemléket. A középkori városok adták az európai civilizációnak a sokoldalúságát, önbizalmát, kezdeményező képességét és azt az óriási szellemi hatalmat, amellyel ma is dicsekedhet. A középkori városok hanyatlása önhibájukból következett be. Végzetes tévedésnek bizonyult, hogy a kölcsönös segítséget nem terjesztették ki a bevándorlókra, az újonnan érkezőket hátrányosan megkülönböztették a céhek tagjaitól. Hatalmukat a kereskedelemre és az iparra alapították, a mezőgazdaságot elhanyagolták. Zsoldos hadsereget fogadtak, óriási kölcsönöket vettek fel, ezért a belső viszályok minden választásnál jobban kiélesedtek. Viszálykodásaik következményeként jelentek meg az autokráciák. A különböző országrészekben egy-egy nagyravágyó hủbérúr szerezte meg a hatalmat. Fokozatosan hatalmas régi római mintára épülő államok jöttek létre.

\section{Kölcsönös segítség napjainkban}

Az állam kisajátított minden szociális összefogást. Minél jobban erősödött az állam iránti elkötelezettség, annál inkább diadalmaskodott az a meggyőződés, hogy az embernek egyénileg kell boldogulnia. Egyre nagyobb teret hódított az individualizmus. A községi földeket, a faluközösségek birtokait fokozatosan eltulajdonították. De e zord időkben is a kölcsönös segítség magvai, a faluközösségek maradványai megmaradtak elszórtan kis területeken, minden drasztikus rendszabály dacára.

Svájcban például a faluközösségeknek a kiterjedt önkormányzatuk révén sikerült megtartaniuk osztatlan tulajdonú földjeiket. Minden kantonban müködik a Burgernutzen, vagyis néhány tehenet közösen tartanak, hogy a családokat ellássák vajjal, közös földjük, szőlőjük van, amelynek termését elosztják a polgárok között. Sok kölcsönösségen alapuló hagyományuk van: dióhámozás, menyasszonyi kelengye varrása, házépítő kalákák, nyelvtanulási célból gyerekcserék, a nehéz munkanapok rutinjából kiemelő közös ünneplések. Svájc a szövetkezetek szülőhelye is: jelen vannak a tejtermékek értékesítéséért szerveződő tejszövetkezetek, illetve különböző egyesületek (tűzoltó, csónakázó, céllövő stb.), melyek a modern militarizmus termékei.

Svájc azonban nem az egyetlen kivétel Európában. A közösségi birtoknak erkölcsi jelentősége, hozadéka is volt: a szegényebbek segítése, a falusi életben a kölcsönösségen alapuló szokások és erkölcsök magvának a megőrzése, a kíméletlen individua- 


\section{OLVASS FELESLEGESET!}

lizmus és kapzsiság kifejlődésének a meggátolása. Ugyancsak a kölcsönös segítség szellemének lehet köszönni a paraszt- és bérlőszövetkezetek létrejöttét, szindikátusok megjelenését. Kezdetben a trágyával és magvakkal való árucsere lebonyolítására hozták létre őket, de később egyre változatosabb tevékenységek közös elvégzésére szolgáltak: árvízvédelem, mezőgazdasági termékek értékesítése, tejszövetkezetek működtetése, erdőgazdálkodások, tógátak, utak, öntözőcsatornák építése. A köztulajdon fenntartása nehézségei ellenére Oroszországban is természetes tendencia volt a parasztság körében. A faluközösségek a munkálatok, tevékenységek többségét közösen, egymást segítve végezték el, sőt közös vagyont is szereztek. Kezdetben a népszokások, néphagyományok és hitvilág a kölcsönös segítség elvére épült, de a tudományok térhódításával egyre inkább elterjedt mindenki harca mindenki ellen elv. Annak ellenére, hogy a modern állam a szövetkezeti faluközösségek szétrombolására törekedett, a parasztok életében napjainkban is jelen vannak a kölcsönösségi szokások, erkölcsök és hálózataik révén megpróbálják fenntartani gazdasági célzatú szövetkezeteiket. Napjainkban a kölcsönös segítségnyújtás az iparos lakosság körében a következőképpen alakult: az állam megpróbálta megsemmisíteni a kézművesek, mesterek és kereskedők céheinek és városainak összetartó erejét, és ő maga kézbe venni a különböző iparágak belső és technikai szervezését. Intézkedéseket hozott a munkáskoalíciók ellen. Az üldözések és nehézségek ellenére, titkos testvériségek mintájára szakszervezetek születtek, föderatív szervezetek alakultak ki, hogy támogassák az egyes szakmabelieket a sztrájkok és üldözések alatt. Hosszú harcok után sikerült kivívniuk az egyesülés jogát. Ma már a legtöbb munkás valamely trade union tagja. A sztrájkolok között megnyilvánuló szolidaritás is a kölcsönös segítség bizonyítéka, pl. a sztrájkalap, segélyezés, egymás segítése. A szakszervezet azonban nem az egyetlen forma, amelyben a munkásnak a kölcsönös támogatás iránti szükséglete kifejezést nyer, müködnek mellette még politikai egyesületek is. A nagy gondolat lelkesítő hatalma, eszménye motiválhat sokakat altruista módon cselekedni, a kártérítés reménye vagy minden személyes dicsvágy nélkül. Kropotkin miközben ezt ecseteli, fölveti a kérdést: „Valóban magam sem tudom, mi a csodálatosabb: ezeknek a keveseknek a határtalan odaadása, vagy pedig a kis tények összege a nagy tömegek odaadásában."

A szövetkezeti mozgalmak legfontosabb jellemzője a kölcsönös segítség, de nem tagadja meg a szövetkezeti egoizmust, „részvényekre alapított invidualizmust” sem. Kölcsönös segítségre épülnek még a segélyező egyletek, az oddfellow páholyok, a falusi és városi betegsegélyező egyesületek, nőegyesületek, társaságok, melyeknek tagjai mindig készen állnak idejüket, egészségüket vagy akár életüket is kockára tenni egymásért. Az emberiség lélektani jellemzője, hogy segítségnyújtással válaszol, reagál a segélykiáltásokra: „az agy szofizmái nem tudják legyőzni a segítségre való készséget az emberek között, mert ezt az érzést az emberi társas élet sok ezer esztendeje és az ember előtti társas élet sok százezer esztendeje nevelte föl" (Kropotkin 1924: 191). 


\section{OLVASS FELESLEGESET!}

A városokban ellenben a közös érdekek hiánya jó táptalajnak bizonyul a közömbösség terjedésének, burjánzásának. Reményt adó tény, hogy a kölcsönös segítség a városokban is megtalálható még néhány helyen: többek között a különböző sportegyesületeknél, ahol hozzájárulhatnak a szociális különbségek enyhítéséhez, elősegíthetik a személyes barátságok, összeköttetések létrejöttét, bizonyos fokig enyhítik a származási, politikai és vallási nézetek közötti különbözőségeket. Nemzetközi szervezetek alakulnak, melyek hisznek abban, hogy elősegíthetik azoknak a gátaknak a lerombolását, melyeket a különböző államok építettek föl a népek között. A kölcsönös segítség gyakorlóinak tekinthetjük még a vallásos szervezeteket, a jótékonysági egyesületeket is.

Mindezek alapján megállapítható, hogy az egyéni érdekek kíméletlen hajszolása tekintet nélkül más emberek szükségleteire nem kizárólagos jellemvonása a modern életnek. A falusi és iparos népesség is a kölcsönös segítség és támogatás állandó alapelve mentén próbálja újra szülni önmagát.

\section{Összefoglalás}

Kropotkin szerint az élet erkölcsi alapelve: „Ne állj bosszút a gonosz cselekedetekért! És adj önként többet, mint amennyit felebarátodtól elvársz!" (Kropotkin 1924: 207).

Könyvében bemutatja ezen elv folytonos fejlődését az állatvilágban, majd az emberi fejlődés lépcsőfokain át az ókortól napjainkig. Következtetésként megállapítja, hogy már az állatvilágban is a társuló fajok a sikeresebbek, s a kölcsönös segítség, a társas erkölcs kifejlődése biztosítja a faj fennmaradását, terjedését és fejlődését. Az emberiség legősibb törzsi szokásai és erkölcsei voltak a csirái minden olyan intézménynek, amelyekből a későbbi haladás fő formái kialakultak. „A kölcsönös segítség működése és fejlődési fokai teremtették meg a társas életnek azt az állapotát, amelyben az ember ki tudja fejleszteni művészetét, tudását és szellemét és hogy azok a korszakok, amikor a kölcsönös segítségre alapított berendezések legjobban fellendültek, egyúttal a művészet, ipar és tudomány legerősebb föllendülésének a korszakai is voltak." (Kropotkin, 1924: 205) Végkövetkeztetésként megállapítható, hogy Kropotkin a társadalmi tőkét fedezte fel, az általa bemutatott kölcsönös segítség, tulajdonképpen a társadalmi tőke előfutára.

\section{Irodalom}

Barash, D. (1977): Szociobiológia és viselkedés, Budapest, Natura Kiadó.

Kropotkin, P. (1924): Kölcsönös segítség mint természettörvény, Budapest, NépszavaKönyvkereskedés kiadása. 